\title{
SEXUAL DIMORPHISM IN FINGER PAPILLARY DERMATOGLYPHIC PATTERNS FOR INDIVIDUALS FROM SOUTH BULGARIA
}

\author{
Nadezhda Petrova, Emilia Andreenko, Sofia Baltova \\ Department of Human Anatomy and Physiology, Faculty of Biology, \\ University of Plovdiv, "Paisii Hilendarski", Bulgaria
}

\begin{abstract}
Summary. The aim of the study is to make a whole morphologic characteristic and to assess the quantitative and qualitative patterns of finger images and sexual dimorphism among individuals from South Bulgaria. We studied a set of dermatoglyphics of 229 subjects from South Bulgaria (69 males, 160 females), clinically healthy, without ties of kinship to one another, aged 18 to 30 years. Rolled fingerprints were obtained by the ink method. Papillary patterns were classified into four main types. The data were analyzed with statistical software. We found pronounced gender differences in the quantitative and qualitative fingerprint patterns. Males have higher values of ridge number and also of Furuhata and Cummins's indices, while in females the higher values are in Poll and Dankmeijer's indices. The existence of gender-dependent expression of fluctuating asymmetry shows a tendency for a more pronounced asymmetry in males, gender related peculiarities in the course of the embryonic period.
\end{abstract}

Key words: dermatoglyphics, sexual dimorphism, Bulgarians.

\section{Introduction}

Biological values of dermatoglyphics are based on the permanence in the organization of papillaty ridges, palms and soles. Once formed during the embryonic period they remain unchanged throughout the life of an individual.

The very early stabilization of skin ridges, between the third and fifth month of fetal development, allows making a direct assessment of the influence of various factors in the process of their formation (Fearon et al., 2001).

If artifacts of different nature appear during the period of ridges formation, they will disrupt their normal differentiation (Mellor, 1992, Tornjova-Randelova, 1986, Weinsten et al., 1999). Apparently, impaired ridges and deviations from the normal configuration can be due only to genetic or prenatal exogenous factors (Danuta, 1983,Markow and Wandler, 1986). The study of possible prenatal factors involvement in the etiology of certain diseases represents an assessment of the extent of fluctuating asymmetry in terms of the dermatoglyphic characteristics (Fearon et al., 2001, Tornjova-Randelova et al., 2005). Fluctuating asymmetry is sign of ontogenetic stability in different types of organisms (Van Valem, 1962).

The aim of the study is to make a whole morphologic characteristic and to assess the quantitative and qualitative patterns of finger images and sexual dimorphism among individuals from South Bulgaria. 


\section{Material and methods}

We studied a set of dermatoglyphics of 229 Bulgarion individuals, 69 males and 160 females, clinically healthy, without ties of kinship to one another, aged 18 to 30 years. There is not advanced selection, the study is transverse and reflects the status of the excerpt.

We took the fingerprints of both hands by the typographical method in a passive way, using the rotary method, and we read them by the methods of Cummins and Midlo, 1961.

We studied papillary finger images for both sexes of left and right hands.

We took into account the following dermatoglyphics: types of papillary finger images $\operatorname{arches}(\mathrm{A})$, loops $(\mathrm{L})-\operatorname{ulnar}(\mathrm{U})$ and $\operatorname{radial}(\mathrm{R})$, whorls $(\mathrm{W})-\operatorname{ulnar}\left(\mathrm{W}^{\mathrm{u}}\right)$, radial $\left(\mathrm{W}^{\mathrm{r}}\right)$ and symmetrical $\left(\mathrm{W}^{\mathrm{s}}\right)$; the total number of finger ridges on the right (TFRCR) and left hand (TFRCL), and the total of both hands (TFRC).

The type model of the papillary finger images was determined through the following indices: Whorl/loop index of Furuhata $=\{(\%$ whorls/\%loops $) \times 100\}$, Arch/whorl index of Dankmeijer $=\{(\%$ arches $/ \%$ whorls $) \times 100\}$, Arch/whorl index of Poll $=\{(\%$ arches $/ \%$ loops $)$ $\mathrm{x} 100)\}$, The pattern intensity index $=\{(2 \mathrm{x} \%$ whorl $+\%$ loop $) / 2\}$.

The data were analyzed with SPSS 8,0 statistical software. Descriptive statistics was used to summarize the data. Student's $t$-test was used to test the differences in fingerprints between the groups. The level of significance was set at $\mathrm{p}<0.05$. We also used chi-square test and Fisher's test and correlational analysis.

\section{Results and discussion}

The papillary finger images were analyzed separately for both sexes and for both hands.

Table 1 presents the frequency of finger images for both sexes on both hands in percentages. The comparisons between the sexes shows: in both sexes ulnar loops are the most common on both hands, while radial loops and arches are the least common.

Distribution of papillary images by fingers shows: Ulnar loops are the most common on fifth finger of right hand in both sexes, as they are more common in females $(83.8 \%)$ than in males $(71.0 \%)$.

Ulnar loops are most common again on fifth finger of left hand, as this time the frequency is higher in males $(85.5 \%)$ than in female $(82.5 \%)$. Radial loops and arches are more on second finger of both hands for both sexes, and radial loops on right hand are more in males $(15.9 \%)$ than in females (14.4\%), while on left hand - vice versa (21.9\% - females 8,7\% - males). Arches on right hand are more common in females $(11.9 \%)$ than in males $(10.1 \%)$, on left hand - vice versa $(11.3 \%$ - females, $17,4 \%$ - males). Whorl images are least common on third and fifth finger of right hand, on left hand - second and third finger in both sexes.

Table 2 shows the average values of ridge number on fingers, TFRCR, TFRCL and TFRC we found that first finger on males has the highest ridge number, followed by fourth, fifth and third finger. There are no bilateral differences in terms of number of ridges in males. In females we found bilateral differences on all fingers apart from fifth finger. First finger of right hand has the highest ridge number of all, and of the left hand - fourth.

TFRC is a sensitive indicator of fetal neural ontogenetic development. The data from our study show that the average values of ridge number on fingers in males and females have bilateral and intersexual differences. In both sexes TFRCR is higher on right hand (59.02 - females, 67.3 - males) than that on left hand (53.69 - females, 64.03 - males), and TFRC total for both hands is higher in males.

We did analysis of a group of key features which reflect the major morphological properties of each complex of dermatoglyphic elements and they are practically all the morphological peculiarities of the studied group. 


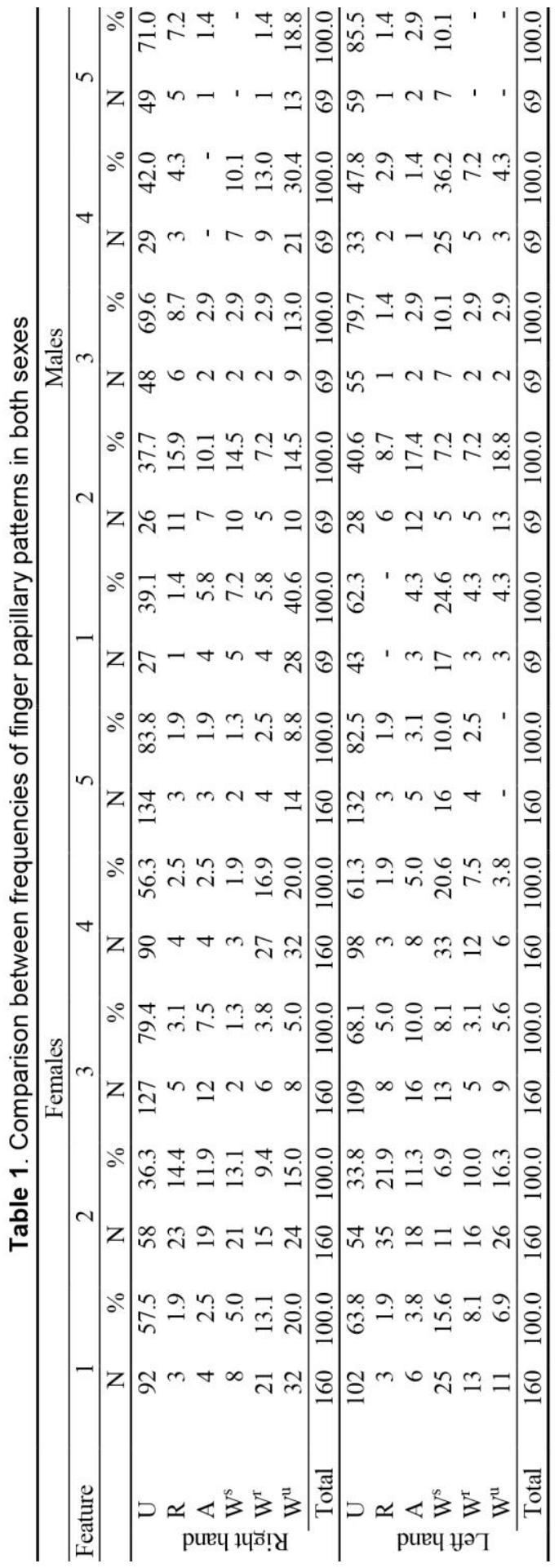

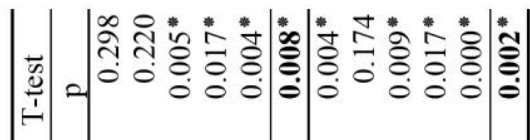
ㄴ.
包
2.

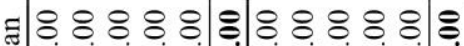
تِ
$\Sigma$
กิำ 8 ㅇำ
m
L

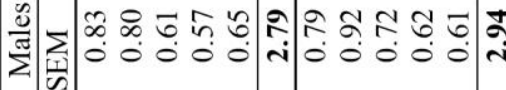

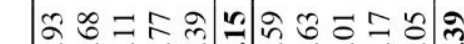
की

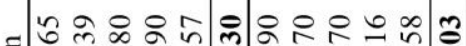
馬

닌

z ํ ริ

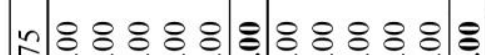

勿向

2.

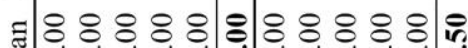

爱

남

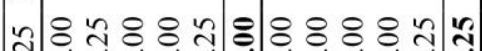

गु

2

$\stackrel{0}{\frac{0}{0}}$

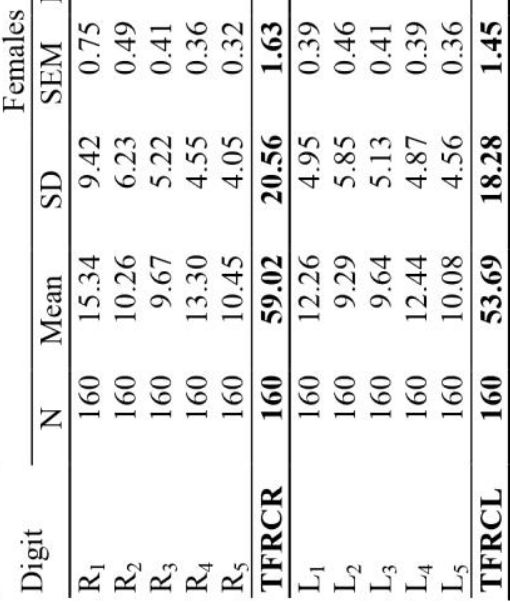




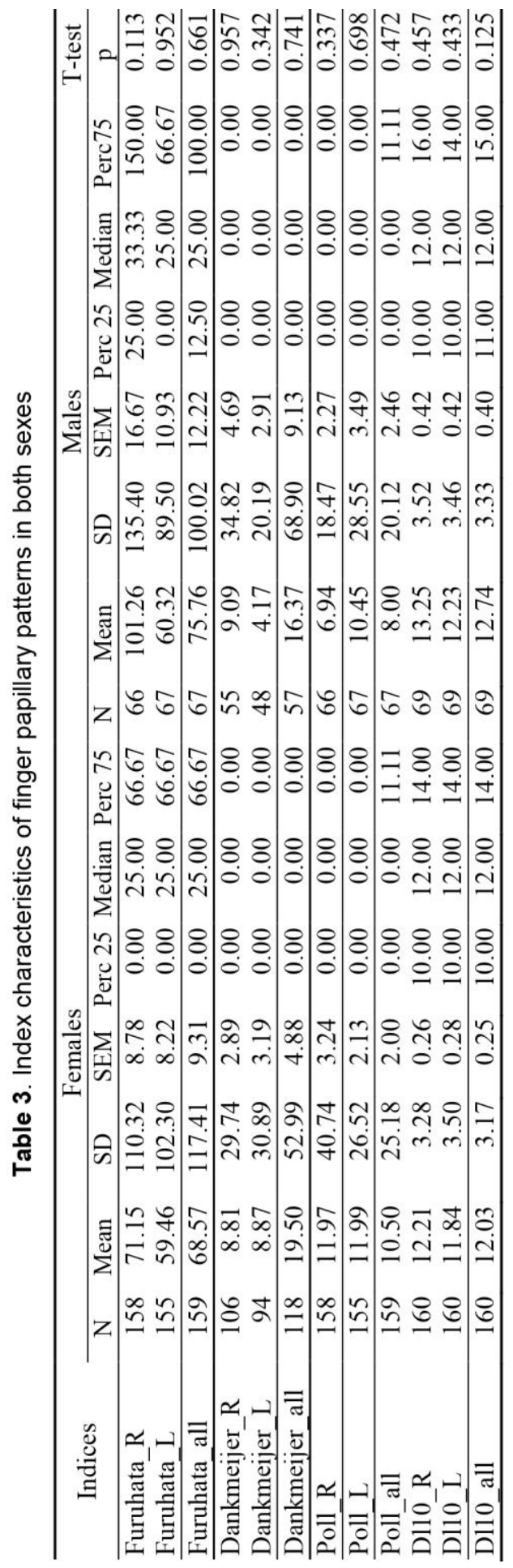

Table 3 shows the calculating of dermatoglyphic indices. We found that Poll and Dankmeijer's indices are higher in females, while Furuhata and Cummins's indices are higher in males. This indicates the presence of intersexual differences.

Our results show, that Bulgarians as a part from European population do not make an exception of dermatoglyphic signs, which characterized her. (Hit and Dolinova,1990, Kavgasova et al.,1999, Kavgasova, 1997, 2004, Schmidt et al.,2008, Tornjova-Randelova and Paskova-Topalova, 2003).

Table 4 shows correlational coefficient and fluctuating asymmetry for finger ridge count in homologous finger papillary images in both sexes. For quantitative signs of finger papillary images the correlational coefficient (r) showed that it is lowest for third finger in males (0.675) than in females (0.729), and for the other fingers it is higher. There are bigger differences for first finger.

In males there are higher values of fluctuating asymmetry (FA) on third finger $(0.544$ in males, in females - 0.469), and for other fingers FA is higher in females.

In FA the differences between homologous right and left structures show a distribution that is different from the normal one which is approximately zero. (Markow, 1989, Schmidt et al., 2008)

The degree of mismatch in the images is used as a criteria for FA.

Table 5 shows percentage distribution of main type papillary images on homologous fingers in males and females. In qualitative dermatoglyphics (A, U, R, W) we found that on second and third finger the percentage of matching is higher in males than in females.

The percentage of loop's matching for third finger is higher in males than in females, and for the other fingers it is higher in females. The percentage of mismatch on second finger is higher in both sexes.

The percentage of arches matching is higher on second finger in males, for the other fingers it is higher in females, and the degree of mismatch is the highest on fifth 
finger in females and on fourth and fifth finger in males. In whorl images the percentage of match in males on all fingers is higher than that in females. The percentage of mismatch has higher values in females on all fingers.

Table 4. Correlational coefficient( $r$ ) and fluctuating asymmetry(FA) for ridge count of homologous fingers in both sexes

\begin{tabular}{ccccc}
\hline \multirow{2}{*}{ Digit } & \multicolumn{2}{c}{ Correlational coefficient $(\mathrm{r})$} & \multicolumn{2}{c}{ FA } \\
\cline { 2 - 5 } & Females & Males & Females & Males \\
\hline 1 & 0.321 & 0.817 & 0.897 & 0.333 \\
2 & 0.683 & 0.766 & 0.534 & 0.413 \\
3 & 0.729 & 0.675 & 0.469 & 0.544 \\
4 & 0.717 & 0.782 & 0.486 & 0.388 \\
5 & 0.743 & 0.842 & 0.448 & 0.291 \\
\hline Total & 0.767 & 0.896 & 0.412 & 0.197 \\
\hline
\end{tabular}

Table 5. Matching and mismatching of the image types on homologous fingers in both sexes (\%)

\begin{tabular}{|c|c|c|c|c|}
\hline \multirow[b]{2}{*}{ Digit } & \multicolumn{2}{|c|}{ Total \% matching } & \multicolumn{2}{|c|}{ Total \% mismatching } \\
\hline & Females & Males & Females & Males \\
\hline 1 & 73.75 & 71.01 & 26.25 & 28.99 \\
\hline 2 & 64.38 & 66.67 & 35.63 & 33.33 \\
\hline 3 & 78.13 & 82.61 & 21.88 & 17.39 \\
\hline 4 & 76.88 & 75.36 & 23.13 & 24.64 \\
\hline 5 & 86.25 & 79.71 & 13.75 & 20.29 \\
\hline \multirow[t]{3}{*}{ Total } & 27.50 & 30.43 & 72.50 & 69.57 \\
\hline & \multicolumn{2}{|c|}{ Loops \% matching } & \multicolumn{2}{|c|}{ Loops \% mismatching } \\
\hline & Females & Males & Females & Males \\
\hline 1 & 49.38 & 37.68 & 50.63 & 62.32 \\
\hline 2 & 36.25 & 34.78 & 63.75 & 65.22 \\
\hline 3 & 66.88 & 71.01 & 33.13 & 28.99 \\
\hline 4 & 50.00 & 36.23 & 50.00 & 63.77 \\
\hline 5 & 78.13 & 72.46 & 21.88 & 27.54 \\
\hline \multirow[t]{3}{*}{ Total } & 11.88 & 4.35 & 88.13 & 95.65 \\
\hline & \multicolumn{2}{|c|}{ Arches \% matching } & \multicolumn{2}{|c|}{ Arches \% mismatching } \\
\hline & Females & Males & Females & Males \\
\hline 1 & 1.88 & 1.45 & 98.13 & 98.55 \\
\hline 2 & 5.63 & 7.25 & 94.38 & 92.75 \\
\hline 3 & 4.38 & 1.45 & 95.63 & 98.55 \\
\hline 4 & 2.50 & - & 97.50 & 100.00 \\
\hline 5 & 1.25 & - & 98.75 & 100.00 \\
\hline \multirow[t]{3}{*}{ Total } & & - & 100.00 & 100.00 \\
\hline & \multicolumn{2}{|c|}{ Whorls \% matching } & \multicolumn{2}{|c|}{ Whorls \% mismatching } \\
\hline & Females & Males & Females & Males \\
\hline 1 & 22.50 & 31.88 & 77.50 & 68.12 \\
\hline 2 & 22.50 & 24.64 & 77.50 & 75.36 \\
\hline 3 & 6.88 & 10.14 & 93.13 & 89.86 \\
\hline 4 & 24.38 & 39.13 & 75.63 & 60.87 \\
\hline 5 & 6.88 & 7.25 & 93.13 & 92.75 \\
\hline Total & 0.63 & 2.90 & 99.38 & 97.10 \\
\hline
\end{tabular}


We found pronounced sex differences in the quantitative and qualitative dermatoglyphics. The bigger asymmetry in homologous structures in high level of FA showed lower body resistance to harmful effects (Dittmar, 1994, Stinson, 1985, Vaclav and Gasiorowski, 2000) and it is significantly valuable in finding prenatal factors (Markow, 1989, Markow and Wandler, 1986, Mellor, 1992, Vaclav and Gasiorowski, 2000).

\section{Conclusion}

1. We found pronounced gender differences in the quantitative and qualitative finger papillary dermatoglyphics.

2. Males have higher values of ridge number and also of Furuhata and Cummins's indices, while in females the higher values are in Poll and Dankmeijer's indices.

3. The existence of gender dependent expression of fluctuating asymmetry shows a tendency for a more pronounced asymmetry in males, gender related peculiarities in the course of the embryonic period.

4. The higher values of fluctuating asymmetry that we found for the quantitative and qualitative signs of finger papillary images in males give us reason to assume that they show greater sensitivity to the early stress conditions and the harmful epigenetic factors of ontogenesis.

\section{References}

Cummins, H., Midlo, C. (1961). Finger prints, palms and soles: An introduction to dermatoglyphics.Philadelphia, Blakinstone. Reprinted: New York: Dover, 319.

Danuta, ZL. (1983). Quantitative Dermatoglyphics: Classification, Genetics and Pathology. Oxford University Press - USA, 450.

Dittmar, MD. (1994). Qualitative and quantitative analysis of digital and palmar dermatoglyphics in Chilean Aymara Indians. Anthropol. Biol., 2, 39-58.

Fearon, P., Lane, A., Airie, M., Scannell, J., McGowan, A., Byrne, M., Cannon, M., Cotter, D., Murphy, P., Cassidy, B., Waddington, J., Larkin, C., O'Callaghan, E. (2001). Is reduced dermatoglyphic $\mathrm{a}-\mathrm{b}$ ridge count a reliable marker of developmental impairment in schizophrenia? Schizophrenia Research, 50(3), 151-157.

Hit, GL., Dolinova, NA. (1990). Racial differentiation of human. Moscow, Science, 3 - 200. (in Russion)

Kavgasova, L. (1997). Anthropological characteristics of a West Rhodope population based on dermatoglyphic data. Acta morphologica et anthropologica, 4, 106-111.

Kavgasova, L., Stoev, R., Mitova, Z. (1999). Dermatoglyphic characteristics of a population from the Central Rhodopes (South Bulgaria). Anthrop. Anz, 57(4), 349-360.

Kavgasova, L. (2004). Dermatoglyphic Characteristics of the Ethnographic Group "Balkandzhii". Acta morphologica et anthropologica, 9, 165-170.

Markow, T. (1989). Gottesman, Fluctuatig dermatoglyphic asymmetry in psychotic twins. Psychiatry Res., 29, 37-43.

Markow, T., Wandler ,K. (1986). Fluctuating dermatoglyphic asymmetry and the genetics of liability to schizophrenia. Psychiatry Res., 19, 32-38.

Mellor, CS. (1992). Dermatoglyphic evidence of fluctuating asymmetry in schizophrenia. Br J Psychiatry, 160, 467-72.

Schmidt, SL., Oliveira, RM., Krahe, TE., Filgueiras, CC. (2008). Finger dermatoglyphics and their asymmetry in Bulgarian right-, mixed- and left-handers. The effects of hand preference and gender on finger tapping performance asymmetry by the use of an infra-red light measurement device. Anthropol Anz., 66(3), 281-93. 
Stinson, S. (1985). Sex difference in environmental sensitivity during growth and development. Yrbk. Phys. Anthropol., 28, 123-147.

Tornjova-Randelova, S. (1986). Dermatoglyphics in healthy children and children with visual insufficiency, inborn deafness, and intellectual disability. Thesis for obtaining degree of "Candidate of medical sciences" BAS, Istitute of morphology, Sofia. ( in Bulgarian)

Tornjova-Randelova, S., Paskova-Topalova, D. (2003). Dermatoglyphic patterns and accessory triradii on the palmar interdigital areas in Bulgarians. J. of Anthropol., 4, 86-95.

Tornjova-Randelova, S., Paskova-Topalova, D., Borissova, P. (2005). Dermatoglyphics of Children with Family-Hereditary Deafness - Fluctuating Asymmetry. Acta morphologica et anthropologica, 10, 258-263.

Vaclav, H., Gasiorowski, A. (2000). Dermatoglyphic analisis of palm prints by the method according to penrose and Loesch. Acta Universitatis palackianae olomucensis Facultas rerum naturalium, Biologica, 38, 97-128.

Valem, VL. (1962). A study of fluctuating asymmetry. Evolution, 16, 125-42.

Weinsten, D., Diforio, D., Schiffman, E., Bonsall, R. (1999). Minor physical anomalies, dermatoglyphicq and cortisol levels in adolescents with schizotypal personality disorder. Am $\mathbf{J}$ Psychiatry, 156 (4), 617-623.

\title{
POLNI DIMORFIZAM NA OSNOVU PAPILARNIH ŠARA NA JAGODICAMA PRSTIJU KOD OSOBA IZ JUŽNE BUGARSKE
}

\author{
Nadezhda Petrova, Emilia Andreenko, Sofia Baltova
}

Sažetak. Cilj ove studije bio je izvršiti analizu morfoloških karakteristika kao i proceniti kvalitativne i
kvantitativne karakteristike šare otisaka prstiju i polni demorfizam osoba iz južne Bugarske.
Uzorkom je obuhvaćeno 229 klinički zdravih ispitanika (69 muškaraca, 160 žena), koji nisu u
krvnom srodstvu, uzrasta od 18 do 30 godina iz južne Bugarske. Otisci prstiju dobijeni su
pomoću mastila. Papilarne šare klasifikovane su u četiri glavne grupe. Podaci su analizirani
pomoću statističkog softvera. Uočili smo izražene kvalitativne i kvantitativne polne razlike u
šarama otisaka prstiju. Kod muškaraca su zabeležene veće vrednosti u broju papilarnih linija
kao i prema indeksu po Furuhati i Kaminsu dok su kod žena zabeležene više vrednosti
Polovog I Dankmeijerovog indeksa.Nestalna asimetrija vezana za pol ukazuje na tendenciju
izraženije asimetrije kod muškaraca, što predstavlja karakteristiku vezanu za pol u
embrionskom periodu.

Ključne reči: dermatoglifika, polni dimorfizam, Bugari 